\title{
A study of prevalence and socio-demographic profile of infertile couples in field practice area of a tertiary care centre, Amritsar, Punjab, India
}

\author{
Moumita Pal ${ }^{1 *}$, Priyanka Devgun ${ }^{2}$, Harsh Chalana $^{2}$, Harpreet Kaur $^{2}$, Atanu Biswas ${ }^{3}$, \\ Sukanta Sen $^{4}$
}

\begin{abstract}
${ }^{1}$ Department of Community Medicine, ${ }^{4}$ Department of Pharmacology, ICARE Institute of Medical Sciences \& Research, Banbishnupur, P.O. Balughata, PIN 721645, Haldia, Purba Medinipur, West Bengal, India

${ }^{2}$ Department of Community Medicine, Sri Guru Ram Das Institute of Medical Sciences \& Research, Amritsar, Punjab, India

${ }^{3}$ Department of Community Medicine, KPC Medical College, Jadavpur, Kolkata, India
\end{abstract}

Received: 30 March 2016

Accepted: 26 April 2016

\section{*Correspondence:}

Dr. Moumita Pal,

E-mail: dr.moumitapal@ymail.com

Copyright: (c) the author(s), publisher and licensee Medip Academy. This is an open-access article distributed under the terms of the Creative Commons Attribution Non-Commercial License, which permits unrestricted non-commercial use, distribution, and reproduction in any medium, provided the original work is properly cited.

\section{ABSTRACT}

Background: Infertility is a global health issue affecting 8 to $12 \%$ of couples worldwide. The objective was to study the prevalence and socio-demographic profile of infertility in the study population.

Methods: The present cross sectional community based study was conducted in the field practice area of SGRD, Amritsar. The socio-demographic profile of the screened infertile couples was taken by filling up the pre-tested proforma. The data was statistically analysed by using SPSS (20.0 versions) IBM Chicago and valid conclusion drawn.

Results: The total number of infertile couples were 291 making the prevalence of infertility $4.57 \%$ [N=6373] with primary and secondary infertility were $1.95 \%$ and $2.62 \%$ respectively.

Conclusions: The prevalence of infertility in the study population was $4.57 \%$ with a primary infertility was $1.95 \%$ and secondary was $2.62 \%$. Among the infertile women $115(39.5 \%)$ were from urban and $176(60.5 \%)$ were from the rural area. Secondary infertility cases were higher in women from both urban and rural area.

Keywords: Infertility, Prevalence, Socio-demographic factors

\section{INTRODUCTION}

Infertility implies apparent failure of couples to conceive while sterility indicates absolute inability to conceive, for one or more reasons. Normally it is observed that $50 \%$ couples conceive within 3 months of regular unprotected intercourse, $75 \%$ in 6 months and $80-85 \%$ conceive within a year. ${ }^{1}$ Children are often desired soon after a couple become sexually active usually through marriage and the failure to produce a child especially a son in some societies is readily recognized by the couple themselves as well as by all those around them. ${ }^{2}$ Thus, infertility is a global health issue. Infertility varies across regions of the world and is estimated to affect 8 to $12 \%$ of couples worldwide. ${ }^{3}$ Underlying these numbers exists a core group of couples, estimated to be 3 to $5 \%$, who are infertile due to unknown or unpreventable conditions. The prevalence of infertility above this level suggests preventable or treatable causes. Infertility tends to be highest in countries with high fertility rates, an occurrence termed "barrenness amid plenty". 4 The incidence of infertility in any community varies between 5 and $15 \%{ }^{1}$

Globally, most infertile couples suffer from primary infertility. The WHO estimates the overall prevalence of 
primary infertility in India to be between $3.9 \%$ and $16.8 \%$. Estimates of infertility vary widely among Indian states from $3.7 \%$ in Uttar Pradesh, Himachal Pradesh and Maharashtra to 5\% in Andhra Pradesh, and $15 \%$ in Kashmir. Moreover, the prevalence of primary infertility has also been shown to vary across tribes and castes within the same region in India. ${ }^{4}$

According to NFHS-3 data of Punjab state women who had primary and secondary infertility constitute 7 and $1.8 \%$ respectively of ever married women between $15-49$ years. A sizeable $79.5 \%$ of ever married women reported to have experienced problems in conceiving for the first time, $11.7 \%$ had problems conceiving after still/live birth and $8.2 \%$ after undergoing induced abortion. More than $10 \%$ of ever married women in Amritsar, Kapurthala, Hoshiarpur, Firozpur, Faridkot and Barnala have infertility problem including primary and secondary infertility.

Despite the existence of an extensive body of the literature on infertility, there are quite a few studies on health-related quality of life in infertile couples. The current study aims to establish the prevalence of infertility, socio-demographic characteristics in the sample.

\section{METHODS}

The study was carried out in the field practice area attached to department of Community Medicine, Sri Guru Ram Das Institute of Medical Sciences and Research, Amritsar, Punjab, India. All eligible couples registered by the health workers of the study area were the study participants. It is cross sectional community based study.

\section{Inclusion criterion}

- The infertile couples (primary and secondary)

- Who are willing to participate

- Who are available during the data collection

The information was collected on a predesigned and pretested proforma from the infertile wives by house to house visit. Study participants were told about the purpose of the study, and confidentiality of the information was assured and informed consent was taken.

At first, all eligible couples under the study population were screened for diagnosing overall prevalence of the primary and secondary infertility. The history of those couples who were diagnosed as having primary or secondary infertility was taken by filling up the proforma.

The proforma included socio demographic profile like age, education, occupation, Socio economic status (SES) etc. SES of the couple was calculated according to the Modified Udai Pareek Scale (MUP Scale). ${ }^{6}$.
The socio economic classes are divided as follows according to MUP score ${ }^{6}$.

- High >28

- Upper-middle 22-28

- Lower-middle 15-21

- Lower $<15$

\section{Analysis}

The data was compiled and statistically analysed using SPSS software(20.0 versions) IBM Chicago and valid conclusion drawn.

\section{Working definition}

\section{Eligible couple}

Currently married couple wherein the wife is in the reproductive age, which is generally assumed to lies between the ages of 15 and 45 years.

\section{Primary infertility}

When a woman is unable to bear a child either due to the inability to become pregnant or the inability to carry a pregnancy to a live birth.

\section{Secondary infertility}

When a woman is unable to bear a child either due to the inability to become pregnant or the inability to carry a pregnancy to a live birth following a previous ability to carry the pregnancy to a live birth.

\section{RESULTS}

The total number of infertile couples were 291 making the prevalence of infertility $4.57 \% \quad(\mathrm{~N}=6373)$. The prevalence of primary and secondary infertility were $1.95 \%$ and $2.62 \%$ respectively in the study population.

The mean age of infertile women included in the study was $29.74 \pm 5.9$ years and mean age of their husbands were $32.69 \pm 6.06$ years. The average age of marriage for women and men was $21.35 \pm 3.63$ years and $24.29 \pm 3.70$ years respectively.

Table 1 shows that maximum primary infertile women $(33.9 \%)$ were in the age group of $21-25$ years and secondary infertility was high (31.7\%) among 26-30 years age group.

Table 2 shows that among the 291 total cases, 115 $(39.5 \%)$ were from urban places whereas $176(60.5 \%)$ were from the rural field practice areas. Secondary infertility cases were higher in women from both urban and rural areas (Table 2). 
Table 1: Distribution of infertile women according to age and type of infertility.

\begin{tabular}{|llll|}
\hline $\begin{array}{l}\text { Age group } \\
\text { (in years) }\end{array}$ & $\begin{array}{l}\text { Primary } \\
\text { infertility }(\%)\end{array}$ & $\begin{array}{l}\text { Secondary } \\
\text { infertility }(\%)\end{array}$ & $\begin{array}{l}\text { Total } \\
(\%)\end{array}$ \\
\hline \multirow{2}{*}{$16-20$} & $\begin{array}{l}10(76.9) \\
(8.0)\end{array}$ & $\begin{array}{l}3(23.1) \\
(1.8)\end{array}$ & $\begin{array}{l}13(100.0) \\
(4.5)\end{array}$ \\
\hline \multirow{2}{*}{$21-25$} & $\begin{array}{l}42(60.0) \\
(33.9)\end{array}$ & $\begin{array}{l}28(40.0) \\
(16.8)\end{array}$ & $\begin{array}{l}70(100.0) \\
(24.0)\end{array}$ \\
\hline \multirow{2}{*}{$26-30$} & $\begin{array}{l}41(43.6) \\
(33.1)\end{array}$ & $\begin{array}{l}53(56.4) \\
(31.7)\end{array}$ & $\begin{array}{l}94(100.0) \\
(32.3)\end{array}$ \\
\hline \multirow{2}{*}{$31-35$} & $\begin{array}{l}16(25.4) \\
(12.9)\end{array}$ & $\begin{array}{l}47(74.6) \\
(28.1)\end{array}$ & $\begin{array}{l}63(100.0) \\
(21.6)\end{array}$ \\
\hline \multirow{2}{*}{$36-40$} & $\begin{array}{l}10(26.3) \\
(8.0)\end{array}$ & $\begin{array}{l}28(73.7) \\
(16.8)\end{array}$ & $\begin{array}{l}38(100.0) \\
(13.1)\end{array}$ \\
\hline \multirow{2}{*}{$41-45$} & $\begin{array}{l}5(38.5) \\
(4.0)\end{array}$ & $\begin{array}{l}8(61.5) \\
(4.8)\end{array}$ & $\begin{array}{l}13(100.0) \\
(4.5)\end{array}$ \\
\hline \multirow{2}{*}{ Total } & $\begin{array}{l}124(42.6) \\
(100.0)\end{array}$ & $\begin{array}{l}167(57.4) \\
(100.0)\end{array}$ & $\begin{array}{l}291(100.0) \\
(100.0)\end{array}$ \\
\hline
\end{tabular}

Table 2: Distribution of infertile women according to residence.

\begin{tabular}{|llll|} 
Residence & $\begin{array}{l}\text { Primary } \\
\text { infertility } \\
(\%)\end{array}$ & $\begin{array}{l}\text { Secondary } \\
\text { infertility } \\
(\%)\end{array}$ & Total $(\%)$ \\
\hline \multirow{2}{*}{ Rural } & $\begin{array}{l}85(48.3) \\
(68.5)\end{array}$ & $\begin{array}{l}91(51.7) \\
(54.5)\end{array}$ & $\begin{array}{l}176(100.0) \\
(60.5)\end{array}$ \\
\hline \multirow{2}{*}{ Urban } & $\begin{array}{l}39(33.9) \\
(31.5)\end{array}$ & $\begin{array}{l}76(66.1) \\
(45.5)\end{array}$ & $\begin{array}{l}115(100.0) \\
(39.5)\end{array}$ \\
\hline \multirow{2}{*}{ Total } & $\begin{array}{l}124(42.6) \\
(100.0)\end{array}$ & $\begin{array}{l}167(57.4) \\
(100.0)\end{array}$ & $\begin{array}{l}291(100.0) \\
(100.0)\end{array}$ \\
\hline
\end{tabular}

Education level of $189(64.9 \%)$ infertile women was above matriculation and $102(35.1 \%)$ had an education below matriculation (Table 3). But the distribution of below matriculation and above matriculation level of education was almost similar in primary (44 i.e. $35.5 \%$ versus 80 i.e. $64.5 \%$ ) and secondary infertility (58 i.e. $34.7 \%$ versus 109 i.e. $65.3 \%$ ) cases.

Table 3: Distribution of infertile women according to education level.

\begin{tabular}{|llll|}
\hline Education & $\begin{array}{l}\text { Primary } \\
\text { infertility } \\
(\%)\end{array}$ & $\begin{array}{l}\text { Secondary } \\
\text { infertility } \\
(\%)\end{array}$ & $\begin{array}{l}\text { Total } \\
(\%)\end{array}$ \\
\hline $\begin{array}{l}\text { Below } \\
\text { matriculation }\end{array}$ & $\begin{array}{l}(35.5) \\
\text { Matriculation }\end{array}$ & $\begin{array}{l}58 \\
(34.7)\end{array}$ & $\begin{array}{l}102 \\
(35.1)\end{array}$ \\
\hline $\begin{array}{l}\text { and above } \\
\text { Total }\end{array}$ & $(64.5)$ & 109 & 189 \\
& $(65.3)$ & $(64.9)$ \\
\hline
\end{tabular}

A little less than one tenth i.e. 9.3\% of infertile women (Table 4) were involved in income generating activities where as majority i.e. $264(90.7 \%)$ of them were house wives.
Table 4: Distribution of infertile women according to occupation.

\begin{tabular}{|llll|}
\hline Occupation & $\begin{array}{l}\text { Primary } \\
\text { infertility } \\
(\%)\end{array}$ & $\begin{array}{l}\text { Secondary } \\
\text { infertility } \\
(\%)\end{array}$ & Total \\
\hline House wife & $\begin{array}{l}109(41.3) \\
(87.9)\end{array}$ & $\begin{array}{l}155(58.7) \\
(92.8)\end{array}$ & $\begin{array}{l}264(100.0) \\
(90.7)\end{array}$ \\
\hline $\begin{array}{l}\text { Income } \\
\text { generating } \\
\text { activity }\end{array}$ & $\begin{array}{l}15(55.6) \\
(12.1)\end{array}$ & $\begin{array}{l}12(44.4) \\
(7.2)\end{array}$ & $\begin{array}{l}27(100.0) \\
(9.3)\end{array}$ \\
\hline Total & $\begin{array}{l}124(42.6) \\
(100.0)\end{array}$ & $\begin{array}{l}167(57.4) \\
(100.0)\end{array}$ & $\begin{array}{l}291(100.0) \\
(100.0)\end{array}$ \\
\hline
\end{tabular}

Table 5 depicts that almost two third i.e. $66.7 \%$ of the infertile couples belonged to joint families.

Table 5: Distribution of infertile couples according to the type of family.

\begin{tabular}{|lll|l|}
\hline $\begin{array}{l}\text { Type of } \\
\text { family }\end{array}$ & $\begin{array}{l}\text { Primary } \\
\text { infertility } \\
(\%)\end{array}$ & $\begin{array}{l}\text { Secondary } \\
\text { infertility } \\
(\%)\end{array}$ & $\begin{array}{l}\text { Total } \\
(\%)\end{array}$ \\
\hline Joint & $\begin{array}{l}91(46.9) \\
(73.4)\end{array}$ & $\begin{array}{l}103(53.1) \\
(61.7)\end{array}$ & $\begin{array}{l}194(100.0) \\
(66.7)\end{array}$ \\
\hline Nuclear & $\begin{array}{l}33(34.0) \\
(26.6)\end{array}$ & $\begin{array}{l}64(66.0) \\
(38.3)\end{array}$ & $\begin{array}{l}97(100.0) \\
(33.3)\end{array}$ \\
\hline Total & $\begin{array}{l}\text { (24) } \\
(100.0)\end{array}$ & $\begin{array}{l}167(57.4) \\
(100.0)\end{array}$ & $\begin{array}{l}291(100.0) \\
(100.0)\end{array}$ \\
\hline
\end{tabular}

Table 6 shows that the maximum (117 i.e. 40.2\%) infertile couples belonged to lower middle class followed by upper middle class (112 i.e. $38.5 \%$ ) according to MUP scale. Only $43(14.8 \%)$ and $19(6.5 \%)$ cases were from upper and lower socio economic status respectively. Maximum primary infertility cases (50 i.e. $40.3 \%$ ) were from upper middle class families where as maximum secondary infertility cases (71 i.e. $42.5 \%$ ) were from lower middle class families.

Table 6: Distribution of infertile couples according to their socio-economic status and type of infertility.

\begin{tabular}{|llll|} 
SES & $\begin{array}{l}\text { Primary } \\
\text { infertility } \\
(\%)\end{array}$ & $\begin{array}{l}\text { Secondary } \\
\text { infertility } \\
(\%)\end{array}$ & $\begin{array}{l}\text { Total } \\
(\%)\end{array}$ \\
\hline Upper & $\begin{array}{l}\text { (\%) } \\
(15.3)\end{array}$ & $\begin{array}{l}24 \\
(14.4)\end{array}$ & $\begin{array}{l}43 \\
(14.8)\end{array}$ \\
\hline $\begin{array}{l}\text { Upper } \\
\text { middle }\end{array}$ & 50 & 62 & 112 \\
\hline Lower & $(40.3)$ & $(37.1)$ & $(38.5)$ \\
middle & $(37.1)$ & 71 & 117 \\
Lower & 9 & $(42.5)$ & $(40.2)$ \\
\hline \multirow{2}{*}{ Total } & $(7.3)$ & 10 & 19 \\
& $(124$ & $(6.0)$ & $(6.5)$ \\
\hline
\end{tabular}




\section{DISCUSSION}

In an international survey, it was concluded that the prevalence of infertility was $3.5 \%$ to $16.7 \%$ in more developed nations and from $6.9 \%$ to $9.3 \%$ in lessdeveloped nations, with an estimated overall median prevalence of $9 \% .^{8}$ A study based on the NFHS-3 (200506) data showed that, in India as a whole, the prevalence of infertility was $2.3 \%$. However it was $1.5 \%$ in the state of Punjab. ${ }^{9}$

Another study at Mysore, India concluded that the prevalence of primary infertility was $12.6 \%(\mathrm{n}=113$; 95\% CI: $10.5-15.0 \%)^{3}$ DLHS-3 of Punjab (2007-08) showed that the women who had primary and secondary infertility constitute $7 \%$ and $1.8 \%$ respectively of ever married women of reproductive age group. ${ }^{5}$

A study among two tribal communities in central India showed the mean age of infertile women among the Khairwars was $31.3 \pm 8.9$ years and $27.5 \pm 9.2$ years among non-Khairwars. ${ }^{3}$ In another study, the mean age of primary and secondary infertile women was found $28.9 \pm 7.9$ and $37.5 \pm 8.6$ years respectively. ${ }^{10}$ The mean age of primary infertile women was $25.9 \pm 3.12$ years in another study conducted at Mysore. ${ }^{4}$ Another study showed the mean age of infertile women was 38.9 \pm 4.9 years at the time of the study. ${ }^{11}$

It was found in a study of West Bengal that, maximum number of infertile women i.e. $108(56.54 \%)$ were in the age group of 25-34 years. ${ }^{12}$ Another study at Bangalore showed that $18(36 \%)$ women were in the age group between $35-39$ followed by 17 (34\%) were in 30-34 years age group, $11(22 \%)$ were in the 25-29 years, $3(6 \%)$ were in 40-44 years and only $1(2 \%)$ were in $45-49$ years age group. The range of age was $25-45$ and the mean age was 33.32 years. ${ }^{13}$ Similarly in another study at Mysore, the maximum i.e. $55.8 \%$ primary infertile women were found in the 21-25 years of age group. ${ }^{4}$

Table 2 findings are in consonance with another study in Egypt. ${ }^{10}$ On the contrary, it was noted in NFHS-2 and NFHS-3 that the infertility rate was higher among women in urban areas compared to women in rural areas. ${ }^{14}$

On contrary, a study of Egypt reported $70.8 \%$ secondary and $64.8 \%$ primary infertile women were illiterate among the study population. Another study reported that $19.5 \%$ were illiterate, $30.1 \%$ had primary, $45.1 \%$ had secondary and $11.5 \%$ had a post secondary education level among the primary infertile women. ${ }^{4}$

Similarly in a cross sectional study of West Bengal, about $75.39 \%$ women were house wives among the infertile women. ${ }^{36}$ In another study, it was reported that majority i.e. $81.4 \%$ infertile women were house wives. ${ }^{4}$

A study conducted in West Bengal, it was found that majority of the infertile couples were from nuclear families. $^{12}$ Another study at Bangalore, $70 \%$ infertile couples among 50 total subjects were from nuclear families. ${ }^{13}$

Women belonging to low standard of living had high infertility compared to women belonging to medium and high standard of living. It was 2.28, 1.86 and $1.93 \%$ respectively in NFHS-2 and 2.17, 1.71 and $1.63 \%$ respectively in NFHS-3. ${ }^{14}$

\section{CONCLUSION}

The prevalence of infertility in the study population was $4.57 \%$ with a primary infertility was $1.95 \%$ and secondary was $2.62 \%$. The mean age of infertile women and their husbands were $29.74 \pm 5.9$ years and $32.69 \pm 6.06$ years respectively. Majority of primary infertile women $(33.9 \%)$ were in the age group of $21-25$ years and secondary infertility was high (31.7\%) among 26-30 years age group.

Among the infertile women 115 (39.5\%) were from urban and $176(60.5 \%)$ were from the rural area. Secondary infertility cases were higher in women from both urban and rural area. Education level of 189 (64.9\%) infertile women was above matriculation and 102 $(35.1 \%)$ had an education below matriculation.

About $9.3 \%$ of infertile women were involved in income generating activities where as majority $(90.7 \%)$ infertile women were house wives. Almost two third (66.7\%) of the infertile couples belonged to joint families. Majority of the couples $(40.2 \%)$ belonged to lower middle class followed by upper middle class i.e. $38.5 \%$ according to Modified Uday Pareekh scale.

Funding: No funding sources Conflict of interest: None declared

Ethical approval: The study was approved by the Institutional Ethics Committee

\section{REFERENCES}

1. Padubidri VG, Daftary SN. The pathology of conception. Howkins \& Bourne Shaw's textbook of gynaecology.15thed. New Delhi: Elsevier, A division of Reed Elsevier India Private Limited; 2011. P.197-220.

2. Balen FB, Inhorn MC. Interpreting infertility: A view from the social sciences. Infertility around the Globe, new thinking of childlessness, gender and reproductive technologies. Berkeley Los Angeles London: University of California press; p.1-32. Available from: http://hrcolumbia.org/gender/papers /vanbaleninhorninterpretinginfer tility.pdf.

3. Kumar D. Prevalence of female infertility and its socio-economic factors in tribal communities of central India.Rural and Remote Health. 2007 [cited 2013 Dec 27]; Available at: 
http://www.rrh.org.au/publishedarticles/ articleprint456.pdf. Accessed 9 Jan 2016.

4. Adamson PC, Krupp K, Freeman AH, Klausner JD, Reingold AL, Madhivanan P. Prevalence \& correlates of primary infertility among young women in Mysore, India. Indian $\mathbf{J}$ Med Res. 2011;134:440-6.

5. International Institute for Population Sciences (IIPS). District Level Household and Facility Survey (DLHS-3) 2007-08, Punjab. Ministry of Health and Family Welfare; 2010. Available at: http://rchiips.org/pdf/india_report_dlhs-3.pdf.

Accessed 9 Jan 2016. Accessed 9 Jan 2016.

6. Pareek U, Trivedi G. Manual of socio economic scale (rural). Manasayan Publishers, New Delhi; 1979.

7. Park K. Demography and family planning. Park's textbook of preventive and social medicine.22nd ed. Jabalpur: M/s Banarsidas Bhanot; 2013. p. 441-78.

8. Boivin J, Bunting L, Collins JA, Nygren KG. International estimates of infertility prevalence and treatment-seeking: potential need and demand for infertility medical care. Human Reproduction. 2007;22(6);1506-12.

9. Syamala TS. Infertility in India: Levels, Trends, Determinants and Consequences. Bangalore: Institute for Social and Economic Change; 2012. 25p. Report No.:WP284 Available from:
http://www.isec.ac.in/WP\%20284 \%20-\%20T\% 20S\%20Syamala.pdf. Accessed 9 Jan 2016.

10. Hassan KES. Prevalence of infertility and its impact on marital fertility, Egypt.1993 [cited 2013 Dec 25]; Available at: http://www.zohry.com/dwb /khassan/pub/infertility.pdf. Accessed 9 Jan 2016.

11. WeghoferA, Kim A, Barad DH, Gleicher N. Age at menarche: a predictor of diminished ovarian function? FertilSteril. 2013;100(4):1039-43.

12. Manna N, Pandit D, Bhattacharya R, Biswas S. A community based study on Infertility and associated socio-demographic factors in West Bengal, India. IOSR Journal of Dental and Medical Sciences (IOSR-JDMS). 2014;13(2):13-7.

13. Mathew B. A descriptive study to assess the attitude of infertile couples towards child adoption in the selected infertility clinics at Bangalore [dissertation]. [Karnataka]: Rajiv Gandhi University of Health Sciences, Bangalore; 2005.151p.

14. Ganguly S, Unisa S. Trends of infertility and childlessness in India: Findings from NFHS data. Facts Views Vis Obgyn. 2010;2(2):131-8.

Cite this article as: $\mathrm{Pal} \mathrm{M}$, Devgun $\mathrm{P}$, Chalana $\mathrm{H}$, Kaur H, Biswas A, Sen S. A study of prevalence and sociodemographic profile of infertile couples in field practice area of tertiary care centre, Amritsar, Punjab, India. Int J Community Med Public Health 2016;3:1472-6. 